\section{AUTHOR}

DEREK C. JONES

Hamilton College, Clinton NY (United States)

djones@hamilton.edu

\section{JEFFREY PLISKIN}

Hamilton College, Clinton NY (United States)

jpliskin@hamlton.edu

\section{MATTHEW POTERBA}

Richard Bernstein Advisors (United States)

matt.poterba@gmail.com

\title{
How Employment Responds to Changes in Assets at US Banks and Credit Unions
}

\section{ABSTRACT}

While US credit unions have one of the highest market penetration rates in the world (more than 40 per cent), they have been rarely investigated by economists. In this study, we use new panel data to provide the first evidence of how US commercial banks and credit unions adjust their employment levels to output shocks. Monitoring by cooperative members leads us to expect that asset quality and growth will differ between coops and investor owned firms. The role of employee-members leads us to predict variation in employment adjustment when assets rise and fall. We find differing employment adjustment responses in reaction to growing versus shrinking assets and across types of firm. Some of our findings point to greater employment resiliency in credit unions. Our results complement findings from studies of workers cooperatives and firms with employee ownership and thus expand the range of alternative institutional arrangements for which evidence exists for greater employment resiliency compared to investor-owned firms (IOFs). Our findings, as does work by others suggest that credit unions and cooperatives were more resilient during the Great recession than IOFs and also point to the economic potential of credit unions and cooperatives compared to IOFs.

\section{KEY-WORDS}

CREDIT UNIONS; BANKS; EMPLOYMENT; COOPERATIVES; LABOR DEMAND. 


\section{Introduction}

The Great Recession has again placed issues surrounding job creation and job destruction at center-stage. In the broad field of industrial relations, the impact of institutional arrangements on employment has long been of interest to researchers. Unsurprisingly, studies of the effects of labor unions on employment continue to figure prominently (e.g., Walsworth, 2010). However, other matters also have a long pedigree. These include the impact of alternative compensation systems such as profit sharing (e.g., Jones and Pliskin, 1989; Kruse, 1991) and the role of alternative employment arrangements (Capelli and Keller, 2013). Also many economists have long conjectured as to how differences in ownership structures might be expected to affect firm behavior (e.g., Megginson and Netter, 2001). However, most empirical work has focused on performance (and often productivity) differences, while work on the consequences of ownership differences for employment, including employment stability is much more limited. This is especially true for financial firms. This absence of literature for financial institutions is especially apparent in view of the effect of the 2008 financial crisis on those firms. The general picture is clear: prior to the crisis, both the size and the complexity of the US financial services sector grew rapidly; in turn, the crisis led to a large number of bank failures and massive employment reductions throughout the industry. However, the precise picture and the key underlying relationships are much less clear. This is the main purpose of this paper-to provide fresh evidence on how two types of US financial institutions, commercial banks and credit unions, adjust their employment levels to output shocks.

As we will discuss below, economic theory suggests that cooperatively owned credit unions would be slower to increase employment when output increases, as well as slower to reduce employment when output falls, because cooperatives place greater importance on job stability than investor-owned firms. The second goal is to contrast the reactions of these firms to positive and negative shocks. Although US workers, especially those employed by nonunionized private sector firms, have less protection against layoffs than in many other industrialized countries, many economists still find that employment is "sticky" - that the level of labor adjusts upward faster than it does downward.

To achieve these aims we make use of new micro data, some of which we have assembled. In this work we note that previous empirical studies of employment adjustment across different ownership structures have examined differences between worker cooperatives and conventional firms (e.g., Pencavel, Pistaferri and Schivardi, 2006; Burdín and Dean, 2009) and have done so for firms in Italy and Uruguay respectively. Apparently, however, there is much less research that focuses on US firms and makes comparisons with firms that are other than worker cooperatives. Moreover, the econometric approaches typically used in these studies of broad samples of firms heroically assume that the determinants of employment adjustment are the same for service and non-service sector firms. In contrast, our work examines employment adjustment in a single industry and does so using a large number of firms. Of course while these features limit the heterogeneity of the sample, this is perhaps at the expense of the ability to generalize our results beyond the banking industry. 


\section{Theoretical and institutional framework}

There is a significant body of theory surrounding the importance of firm ownership for firm behavior (e.g., Fama and Jensen, 1983). Since ours is not a theoretical contribution our brief review highlights the ways in which varying ownership structures, and the role of co-op members (and especially employee members) may be expected to be related to differences in monitoring, asset and loan quality and growth, and employment adjustment across firms. In turn, this leads us to identify four specific hypotheses concerning employment adjustment in credit unions. To those ends, however, we believe it is important to first discuss important institutional differences between commercial banks and credit unions ${ }^{1}$.

There are important differences between commercial banks and credit unions in their structures of ownership and control. As investor-owned firms (IOFs), commercial banks have stockholders who vote for a board of directors, and the board determines profit distribution and can replace managers as necessary. Typically, stockholders are not employees. Those holding shares of listed companies are able to buy and sell shares easily and with low transaction costs through exchanges. Stockholders of unlisted firms often incur higher costs (including difficulties with valuation), though in many cases they are often able to transact with relative ease. Voting rights at commercial banks are allocated based on the number of shares owned. By contrast, credit unions are mutually owned by their members ${ }^{2}$. To join a credit union, members are typically required to pay a small fee. Members are usually not required to hold deposits (although most do) with people joining to access rates on mortgages and other loans that are lower than at investor owned banks. Importantly, members at credit unions, who including employee who are members, each receive one equalweighted vote, regardless of capital investment with the firm.

Important implications for the basic operation of these firms flow from these formal differences. In theory, IOFs, such as commercial banks, should maximize the welfare of their shareholders, or "owners of capital" while credit unions, which are mutually owned, should strive to maximize member welfare. In practice, several considerations lead to a more nuanced view of the objectives of both types of firms. Thus for IOFs principal-agency issues may lead to the firm's managers pursuing goals other than simple profit maximization. For credit unions as well realities may be

\footnotetext{
Historically, there were significant discrepancies in regulations imposed on commercial banks and credit unions in the US. However, this gap has quickly shrunk over the past two decades and since 2000 , the regulatory frameworks are quite similar. However, despite the widespread deregulation of the 1980s and 1990s, Walter (2006) notes that the impact of these historical restrictions on credit unions is still visible today. In $2011,75 \%$ of credit unions had fewer than USD 100 million in assets, compared with $20 \%$ of banks. On the growth of US credit unions, see also Goddard, McKillop and Wilson (2002).

2 However, membership is restricted to a group of people with a "common bond". Although this used to be a highly restrictive barrier to credit union expansion, it has been weakened over the past few decades. See Emmons and Schmid (1999).
} 
more complicated. Thus, Rasmusen (1988) argues that since managers typically control decisions, managers operate credit unions in a manner that limits risk of asset volatility and insolvency instead of maximizing member welfare. Since the compensation of credit union managers is typically based less on profitability than compensation of managers of IOFs, credit unions would avoid risky investments, which should also limit asset volatility. Thus, we predict that credit unions are less likely to experience severe financial crises that would require layoffs which are disproportionately large. A corollary of this is that when the overall economy experiences a severe financial crisis, the conservative lending practices of credit unions would lead to a smaller adjustment in employment than would be the case for commercial banks that engage in more risky activities.

In addition, the role of employees in credit unions is apt to be different from the role played by employees in IOFs. Importantly, in credit unions the firm's employees are members; as such, as a group, employee-members can be expected to have much more significant influence over policy than do workers in IOFs. Evidence of the subtle ways that employee influence in co-op banks leads to different outcomes than in IOFs is apparent in various studies. Thus, Jones, Kalmi and Kauhanen (2012) report evidence on training and wages for co-op banks in Finland ${ }^{3}$. The websites of many US credit unions also point to the differing role of employees. For example, the Navy Federal Credit Union is the largest credit union in the world, both in asset size and in membership. Its

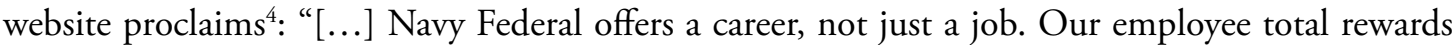
package includes competitive salaries, incentive programs, comprehensive medical/dental/vision benefits, retirement plans with employer match, award-winning training programs, professional development programs, tuition assistance, paid leave, and work/life programs....[And] Job stability is one of our advantages —we've never had a layoff in the history of our organization" (italics added) ${ }^{5}$.

As Ferri, Kalmi and Kerola (2014) discuss, banks owned by their depositors are oriented to serving the interests of their members or customers rather than focusing primarily on their financial performance. In many cases, one might expect that this philosophy is likely to lead to a "corporate culture" that values the contributions of employees, thereby making credit unions, such as Navy

For US credit unions, the only article on employment stability we were able to unearth is Patin and McNiel, (1996). However, their focus in not on employment in individual credit unions but rather employment in the "parent organizations" or credit unions.

4 See https://www.navyfederal.org/about/careers.php

5 Unfortunately, there are no systematic data available that investigate the objectives, role and power of employees in US credit unions. However, there is additional suggestive evidence. For example, while we have not undertaken a comprehensive search of mission statements of US credit unions we were able quite quickly to uncover other expressions of sentiment favouring employees. See, for example, the Roanoke Valley Community Credit Union (https://www.rvccu. org/about/). Also there is additional anecdotal evidence that points to an enhanced importance for job security in US credit unions. See, for North Carolina State Employee's credit union, https://www.glassdoor.com/Reviews/NC-StateEmployees-Credit-Union-job-security-Reviews-EI_IE24155.0,31_KH32,44.htm and for Credit Union 1 https://www. indeed.com/cmp/Credit-Union-1/reviews. 
Federal Credit Union, reluctant to lay off workers during downturns. Moreover, as Jones and Kalmi (2015) argue in the case of Finish cooperative banks, members might have a greater commitment to their credit unions than do depositors and borrowers at commercial banks. This commitment is likely to include credit union employees, especially the front line workers who directly assist members on a regular basis. Thus, the managers of credit unions might antagonize members if workers were dismissed. If credit unions are less inclined to lay off workers during economic downturns, they might be less aggressive than commercial banks in hiring workers during period of growth, unless managers are confident that the expansion is permanent.

From these institutional distinctions, important differences in monitoring mechanisms across IOFs and credit unions emerge. One is the oversight of agents (managers) by principals. While there does not appear to be any systematic evidence available on this point for US credit unions, there is theoretical and empirical evidence for cooperatives. For example, Fulton and Lang (2006) suggest the magnitude of the agency problem is greater in credit unions than in investor-owned firms because typically there is a larger disparity between the interests of owners and managers, since the owners are shareholders at commercial banks but are depositors at credit unions. Fraser and Zardkoohi (1996) also note than potential inefficiencies in IOFs are mitigated since shareholders elect a board of directors that closely monitor firm decisions. Shareholders are also able to discipline underperforming banks through market mechanisms.

However, since primarily depositors own credit unions, once credit unions received deposit insurance coverage in 1970 the members had less incentive to monitor managers closely. Before 1970 , credit union members were typically more aggressive in monitoring managers in an attempt to increase loan quality control, but after deposits at credit unions became guaranteed by the NCUSIF in 1970, members reduced their monitoring effort. This monitoring change was a direct result of a reduction in member monitoring incentives, since personal investment in the credit union, in the form of a deposit, was insured. Therefore, Fraser and Zardkoohi (1996) assert that managers at credit unions have incentives to maintain a lower than optimal risk portfolio, as it reduces risk of insolvency and asset volatility, thereby increasing job security and employment stability ${ }^{6}$.

The second type of monitoring common at both banks and credit unions is loan oversight. The above argument by Fraser and Zardkoohi (1996) that managers at cooperatives take less risk would seem to imply that managers at those institutions would more closely monitor loan quality. Additionally, since credit unions require customers to pay a fee to join before taking advantage of loan and savings service, managers may be able to more accurately screen borrowers and reduce risk on loans though this built-in monitoring mechanism ${ }^{7}$. Walter (2006) asserts credit unions traditionally had a significant advantage over banks in monitoring loan quality, as their small size and

\footnotetext{
6 Of course, these processes are expected to be more powerful in worker cooperatives and indeed there is evidence of wage adjustment but stable employment in response to output price shocks for such firms (Craig and Pencavel, 1992).

7 Typically the actual practice varies slightly for non-members insofar they would first apply for a loan and then if it is approved join and pay the membership fee.
} 
"common bond" of members enabled the more accurate assessment of borrower creditworthiness. Rasmusen (1988) notes credit unions traditionally relied on relationships as a critical mechanism to supplement incomplete and inaccurate information. However, the great strides in the quality of information available on borrowers, particularly due to the rise of national credit rating agencies in the 1980s, reduced information asymmetry between lenders and borrowers. Thus, the edge that credit unions had over banks in the past has been mitigated through improved information ${ }^{8}$. Another potential cause for the breakdown of this "relationship lending" mechanism may be the growing size of credit unions as they attempt to compete with a deregulated banking sector. In his discussion of US credit unions, Ferri (2012) agrees asserting that the degeneration of "relationship lending" at credit unions poses a huge potential problem for credit unions going forward.

If "relationship lending" is more important in credit unions than in commercial banks, then credit unions would benefit more from having a stable group of loan officers who are familiar with and who have developed personal relationships with potential borrowers. In such a situation, credit unions would be less inclined to layoff loan officers when lending opportunities decline. If so, one might expect credit unions to hire more conservatively when demand for loans grows.

Based on the foregoing, we identify three hypotheses that focus on the effects of a change in the commercial bank or credit unions own output.

$\mathrm{H} 1$ : When there is drop in the firm's business, including during a severe financial crisis ${ }^{9}$, credit unions would reduce employment by less than a similar commercial bank.

H2: When the firm's business expands, credit unions would expand employment by less than a similar commercial bank.

H3: Employment stickiness: For both credit unions and commercial banks, the employment response to a drop in business will be smaller than the response to an expansion.

\section{Empirical strategy}

While previous studies of employment adjustment in firms with varying organizational forms use different approaches, there do appear to be systematic differences by field. Thus, studies in labor are numerous though recent literature seems to favor estimating first-difference models. For example, Pencavel, Pistaferri and Schivardi (2006) utilize this specification to measure how changes in wages, fixed costs, costs of capital, and product market demand affect employment at both

\footnotetext{
8 However, the role of national credit rating agencies during the crisis does not lead one to accept this development uncritically. See also Klinedinst (2012).

9 Since credit unions and commercial banks are unlikely to have similar portfolios (e.g., Klinedinst, 2016), credit unions might have been expected to cut employment less simply because they had less exposure to toxic investments such as sub-prime loans. Unfortunately, we have no easy way of testing for this alternative hypothesis.
} 
co-op and capitalist firms across a wide spectrum of industries. Burdín and Dean (2009) use a similar approach ${ }^{10}$. Their data include firms from numerous industries and likely include few firms from the financial sector ${ }^{11}$. By contrast, research in finance on employment adjustment in banks and other financial institutions is scarcer and uses other approaches. For example, Kumbhakar, Heshmati and Hjalmarsson (2002) analyze how quickly banks adjust employment to their efficient level using a dynamic model with a bank-specific and time varying adjustment parameter. The use of a flexible-form allows them to generate a labor-requirement frontier, specified by the number of branches, the type of bank, and the size of a bank ${ }^{12}$. Another feature of the empirical work on banks is the absence of a standard measure of output, likely due to both their fundamental complexity and their production of multiple outputs ${ }^{13}$.

After reviewing the various specifications, we base our analysis on the first-difference models of Pencavel, Pistaferri and Schivardi (2006) and Burdín and Dean (2009), though some modest changes to their specifications were necessary to adapt their multi-industry models to our observations for only banks and credit unions. One complicating factor was the selection of a measure for output at both banks and credit unions. We select total assets as the best approximation of firm output, since it seems reasonable that the services provided to customers are proportional to that bank's asset base. Moreover, assets are comparable between credit unions and banks and information on assets is widely available. The general specification (1) is given below for firm $i$ at time $t$. The determinants of changes in the natural logarithm of employment $\mathbb{\nabla}\left(\Delta \ln E \rrbracket_{i t}\right) \mathbb{\nabla}\left(\Delta \ln E \rrbracket_{i t}\right)$ at commercial banks and credit unions include changes in total assets $\mathbb{\nabla}\left(\Delta \ln A \rrbracket_{i t}\right) \mathbb{\mathbb { }}\left(\Delta \ln A \rrbracket_{i t}\right)$, changes in wages $\left(\Delta \ln w_{i t}\right)\left(\Delta \ln w_{i t}\right)$, a vector of control variables $\left(\mathrm{C}_{i t}\right)$ for institution size (which is measured by employment) ${ }^{14}$ and time (see Table 1 for variable definitions). Since we are interested in asymmetries, the model will be estimated over a long period that encompasses both booms and recessions.

$$
\Delta \ln E_{i t}=\beta \Delta \ln A_{i t}+\gamma \Delta \ln w_{i t}+\tau \mathbf{C} i t+F_{i}+\varepsilon_{i t}
$$

\footnotetext{
10 An alternative approach would be to follow Kurtulus and Kruse (2016) who use least-squares models to predict how firms performed over the 1999-2008 period, based on whether the firm had employee ownership programs and the level of employee involvement in such programs.

11 Most of the cooperatives in the study of Pencavel, Pistaferri and Schivardi (2006) are not in manufacturing-in contrast to the capitalist firms. For Burdín and Dean (2009) also there is not a large fraction of cooperatives in manufacturing, and the biggest sector is transportation.
}

12 An earlier study by Taylor (1979) estimates a Cobb-Douglas production function to study the labor demand at credit unions.

13 Altunbas, Evans and Molyneux (2001) consider deposits and branches as inputs while Craig (1997) argues that total assets are a good measure of banking output. However, in their comprehensive survey, Berger and Mester (1997) note that many other variables have been considered as inputs or outputs including loans, capital and deposits.

14 Three size categories are used, namely whether a firm employs (i) between 10 and 99 employees; (ii) 100-249 workers; or (iii) more than 250 employees. These particular categories are chosen in large part to reflect the lower average and median sizes of credit unions comparted to commercial banks. 
Model specification (1) uses a first-difference approach to predict how a firm will change its labor input in reaction to shocks in its output or the cost of the labor input. Theory suggests that $\beta$ should be positive, as a positive shock to output will require input to increase to remain in equilibrium. Since profit is allocated to customers in a credit union, we do not expect credit unions to behave like labor-managed firms. In fact, the standard theory of factor demand applies and indicates that an increase in wages should reduce the demand for labor and thus, $\gamma$ is expected to be negative. $C$ denotes a vector of control variables, mainly year effects and three categories for firm size, and $F_{i}$ is a firm-specific fixed effect. The use of fixed effects in the first-indifference specification above (1) allows firms to have different linear time trends.

Berger et al. (2005) find that, in contrast to small banks, large banks rely more on financial information in assessing the credit risk of potential borrowers and "interact more impersonally with their borrowers", with who they tend to have "shorter and less exclusive relationships". To identify the effect of differences in ownership structure, we will control for firm size in some of our models. Although today we find that commercial banks and credit unions face similar regulatory environments and have several similar characteristics, we argue that institutional inertia in some cases has resulted in the persistence of pre-deregulation employment and wage practices today in credit unions. Accordingly, it is preferable to estimate the models for commercial banks and credit unions separately. The hypothesis that employment adjusts differently to shocks for the two types of financial institutions can be tested through a comparison of the coefficients across the two estimated models. A more common approach in the previous literature (e.g., Pencavel, Pistaferri and Schivardi, 2006; Burdín and Dean, 2009) is to estimate using the entire sample of firms the above model augmented with ownership-interaction terms to test whether firms with different ownership structures adjust employment differently. Further, the estimation of one model with interaction terms constrains the variance terms $\varepsilon_{\mathrm{i}}$ to be equal across all sub-groups of firms, and given the differences described above, this may be a restrictive assumption. Nevertheless, we also estimate the combined model, using interaction terms between institution type and changes in assets and wages as a robustness check.

In addition to the core fixed-effects model (1) described above using panel data for many years, it is helpful to estimate supplementary cross-sectional specifications that focus on employment changes in just a single year. These allow one to test whether the fundamental relationship between labor and output growth for a given type of institution changes over the years in our sample. These cross-section model specifications enable us to test whether employment is more sensitive to changes in output during periods of recession, including during the great recession and its aftermath. If the basic relationship between employment and output does indeed change over-the-cycle, then this would indeed have implications for the specification of our fixed-effects model.

Although specification (1) does allow for employment adjustment differences across different types of financial institutions, it is unable to capture potential adjustment asymmetry between periods when output is growing versus contractions. As mentioned earlier, theory and previous research both suggest that employment is somewhat sticky at firms, implying that employment 
adjusts more to growing output than falling output. Therefore, we construct a dummy variable Shrink, which indicates whether total (real) assets fell between the previous period and the current period. By interacting Shrink with $\Delta \ln A$ we are able to compare how much employment changes when assets are shrinking and growing. For ease in interpreting coefficients, we interact $\Delta \ln A$ with another generated dummy, Grow, which is 1 when Shrink is 0 . This creates two distinct measures for the elasticity of employment adjustment; one when firms are growing, defined as growth in real assets from the previous year, and one when firms are shrinking, defined as a decrease in real assets from the previous year. The dummy variable Shrink is also included in the regression by itself. Fixed-effects remain important, as they control for different average growth rates across firms. We also include the Shrink variable alone, so that any effects of the asset growth crossing from positive to negative will not affect the estimates of the coefficients on changes in assets. This modification, shown below in specification (2), enables tests for employment stickiness and for asymmetry of employment adjustment during periods of increasing assets and shrinking assets.

$\Delta \ln E_{i t}=\llbracket \beta\left(\Delta \ln A \rrbracket_{i t} * \operatorname{Grow}_{i t}\right)+\llbracket \varphi\left(\Delta \ln A \rrbracket_{i t} * \operatorname{Shrink}_{i t}\right)+\gamma \Delta \ln w_{i t}+\rho \operatorname{Shrink}_{i t}+\tau C+F_{i}+\varepsilon_{i t}$

In selecting independent variables to include in this analysis, we confront the perennial problem of endogeneity. Since firms are able to choose the level of their labor inputs, any variables that could be similarly chosen by firms were excluded from our analysis. While there were a number of measures that were straightforward to rule out, such as net income, there is the potential concern that firms may be able to choose both employment and wage simultaneously. However, we think that, since both credit unions and commercial banks hire in similar labor markets, we believe this is less of a concern.

\section{Data and descriptive statistics}

To study employment responses to asset shocks at financial institutions we combine data on US credit unions from the National Credit Union Administration with data on US commercial banks from Bankscope. The NCUA provides balance sheet and income statement financials for individual credit unions on a quarterly basis between 1999 and 2010. The measures selected were ratios and levels from the December 31 reports. Much economic research on credit unions in the US uses the publicly available data provided by the NCUA (e.g., Wilcox and Dopico, 2011). Bankscope data are balance sheet and income statement financials for individual banks in the US on an annual basis for the same period. Much of the recent econometric work on the performance of financial institutions in Europe and the US uses these Bankscope data (e.g., Ferri, Kalmi and Kerola, 2014). Bankscope data are generally regarded as being both highly reliable and complete, though many researchers report the need to re-code particular variables (as do we, see on). Annual state unemployment rates from the Bureau of Labor Statistics supplemented these two core datasets. 
Before using the data for empirical analysis, we had to make several adjustments. The NCUA data required our merging quarterly data files into annual ones and then merging these annual records with corresponding information from Bankscope in order to form the sample. We adjust all "value" variables in the NCUA data by dividing by 1,000, thereby putting Bankscope and NCUA data in the same units. We also construct a balanced panel from the original unbalanced data by imposing a number of exclusion rules, thereby increasing our confidence in the datasets.

SAs far as individual variables are concerned, we undertake adjustments concerning the measurement of full time equivalent employees and deposits. Employment data are included in both the underlying datasets, but is reported somewhat differently for the two cases. The FDIC requires US banks to list fulltime equivalent employees in call reports. However, the NCUA call reporting standards indicate that credit unions report employment by full-time employees and part-time employees. NCUA literature provides the following formula for guidance on calculating full-time equivalent employees:

$$
\text { FTE employment }=(\text { full }- \text { time employees })+\frac{\text { part }- \text { time employees }}{2}
$$

We use the NCUA formula to obtain full-time equivalent employment data for credit unions that is comparable to the employment reported by banks.

Since "deposits" are measured differently in the Bankscope and NCUA datasets, another adjustment is required. At commercial banks, customers make deposits and banks report total deposits. However, at credit unions, "deposits" exclude money that members have paid in order to purchase a "share" and become a member. Thus, to compare output using this measure, commercial bank "deposits" are compared to credit union "shares + deposits".

Another issue, prompted by examining the raw data from Bankscope and the NCUA, is that data may be unduly affected by a few large firms and by mergers and acquisitions. From Table 3 we see that mean employment is largest for commercial banks and smallest for credit unions, which seems loosely correlated with total assets. We calculate the implied growth rate in mean and median employment from 1999 to 2010 for both types of firms and note that growth is skewed towards larger firms in each case. Credit unions experienced 52 per cent growth in mean FTE from 1999 to 2010 but only a 41 per cent increase in median FTE; the corresponding numbers for commercial banks are 59 and 38 per cent respectively. This is one reason for including fixed-effects in specifications (1) and (2) as a way to control for different growth rates both for similar firms and for firms across different institutional groupings.

To construct the panel we implement three exclusion rules. First, we exclude all institutions with fewer than 10 employees. To prevent very small firms from throwing off results most econometric research on employment adjustment at manufacturing firms imposes a constraint on the minimum number of employees at a firm-it is believed that employment adjustment may be "lumpy" when the values are so small. Since financial institutions typically require less labor for a given firm size than do manufacturing firms, our analysis has been restricted to banks and credit unions with at least 10 employees. Imposing this constraint on our data reduces the sample size by 0.8 per cent for commercial banks, and 5.2 per cent for credit unions. 
Second, we restrict the panel to banks and credit unions that remained in the industry for the entire sample period, thereby excluding firms that exited the industry through acquisition or failure. Although this reduced the sample size for banks and credit unions somewhat, it created a balanced panel. We manually sifted through these data and marked banks that acquired another firm between 1999 and 2010, as we hoped the elimination of these banks from our balanced panel would provide a clearer view of how financial institutions adjust employment when organic shocks to assets occur, rather than through forced growth by acquisition ${ }^{15}$.

Finally, we delete extreme outliers ${ }^{16}$. Specifically we remove banks and credit unions with observations that were farther than two standard deviations from the annual mean of $\Delta \ln A$ for that institution group. The small number but large magnitude of outliers present in the sample, quite apparent when graphing $\Delta \ln A$ versus $\Delta \ln E$ on a per-year basis, motivated this reduction. This constraint leads to only a few observations for banks and credit unions being removed from our sample.

Table 2 provides a summary of the resulting panel. We end up with a panel of 6,845 banks during the 12-year period. There are about twice as many commercial banks as credit unions in this balanced panel. The size distributions by type of institution differ, as we would expect, with proportionately more large commercial banks.

Since the data collected span a period of 12 years, it was necessary to convert all current dollar variables into real values. For all value variables, with the exception of personnel expense, we convert into 2005 chained USD using the annual GDP deflator data from the Bureau of Economic Analysis. For personnel expenses, however, we follow the literature (e.g., Burdín and Dean, 2009) and convert to 2005-chained USD using annual CPI measures from the Bureau of Labor Statistics ${ }^{17}$.

Our key descriptive statistics are reported in Table 3 where we see that mean employment is higher in commercial institutions than at credit unions over all sample years. Although mean employment would seem to indicate that the "typical" commercial bank employs over three times as many people as the "typical" credit union (243 compared to 74), median employment statistics tell a different story. The medians across institutions are closer, ranging in value from 36 for credit unions to 42 for IOFs. This indicates the presence of huge firms in commercial banking that pull mean employment upwards. This is confirmed by the descriptive statistics for total assets: mean total assets at commercial banks are about over 480 per cent larger than credit unions, but median assets are only 150 per cent as large. Turning to wages, on average commercial banks pay about USD 4,000 more than do credit unions. This probably reflects larger average size and different types of workers.

\footnotetext{
15 Since financial institutions that lose assets may go either bankrupt or be acquired by other institutions, this selection rule may affect results.

16 Data errors, unreported M\&A activity, or extreme circumstances that do not represent general financial institution behavior are a few potential reasons for these extreme outliers.

17 As discussed later, the inclusion of real mean wages, calculated using the same method (see Table 1) as Burdín and Dean (2009) and many others, might introduce a division bias problem, since errors in the employment variable will affect the calculated value for real mean wage.
} 


\section{Results}

We begin by summarizing our key findings concerning the first two hypotheses surrounding employment adjustment in credit unions and commercial banks including whether or not there are asymmetries during periods of growth and contraction. We then turn to more carefully discuss our findings, which are reported in Tables 4 through 8.

We find that Hypothesis $\mathrm{H} 2$ is supported: the elasticity of employment adjustment is larger for commercial banks than for credit unions when the firm's assets grow. However, we do not find strong support for the hypothesis (H1) that the adjustment in employment following a drop in assets is smaller for credit unions. We consistently find that commercial banks exhibit statistically significant employment stickiness (Hypothesis $\mathrm{H} 3)^{18}$. There is weaker evidence that credit unions respond to asset shocks asymmetrically as well. Finally, the year dummy variables indicate that both credit unions and commercial banks reduced employment significantly more than past experience would have predicted during the recession from 2008-2010, but the employment reduction at credit unions was not smaller than at commercial banks.

In arriving at these conclusions, we begin by reviewing our panel estimates. We first estimate our core model, specification (1). This model allows for tests of whether the asset elasticity of employment is significantly different for the two types of firms (see Table 4). Although specification (1a) does not include fixed-effects, both (1b) and (1c) use fixed-effects to control for different growth rates across firms. Year dummy variables have also been included to control for macroeconomic trends affecting all firms in specification (1c). We note that the lack of fixed-effects in (1a) does not produce any qualitatively different results, though there is a large decrease in the credit union coefficient on assets. The estimation of coefficients across these two specifications illustrates that year effects do have an impact on coefficients, but it is small. While the coefficients on $\Delta \ln w$ remain virtually unaltered the term on $\Delta \ln A$ for credit unions increases when year effects are included.

The results reported in columns (1b) and (1c) of Table 4 indicate that commercial banks adjust their employment more to changes in assets than do credit unions and that these differences are statistically significant at the 1 per cent level. While this supports our hypothesis about how the two types of firms behave, the estimated difference is modest, especially the results reported in column (1c), where year effects are included. As discussed earlier, one of the shortcomings of model (1) is the inability to test for asymmetries in employment adjustment for positive and negative growth in assets. Model (2) allows for this. We report in Table 5 four variants of specification (2) that differ whether firm fixed effects are included (columns 2b, 2c, and 2d), time effects are included (columns $2 \mathrm{c}$ and $2 \mathrm{~d}$ ) and whether size dummies for medium and large firms are included (column $2 \mathrm{~d}$ ). We find that commercial banks always exhibit a highly statistically significant ( $\mathrm{p}$ value is virtually

\footnotetext{
18 We recognize that this finding is also consistent with other hypotheses such as the likely greater use of flexible pay schemes in commercial banks compared to credit unions. Unfortunately, we do not have data to enable us to control for the potential impact of such differences between organizations.
} 
0) greater employment adjustment response when assets grow compared to when assets fall. In contrast, evidence for employment stickiness for credit unions is weaker. When firm fixed effects are included, the difference in the response of employment to growing assets compared to falling assets is statistically significant only in columns (2c) and (2d) with p values of .066 and .056 respectively. Moreover, the magnitude of the difference in adjustment is much smaller for credit unions than for commercial banks. In addition, we find that when firm fixed effects are included, commercial banks adjust their employment more to increases in assets than do credit unions and that these differences are statistically significant at the 1 per cent level. In contrast, the response of commercial banks to falling assets is not statistically different from that of credit unions when both firm and year fixed effects are included. Thus, it appears that commercial banks hire more aggressively when their assets grow, while credit unions prefer smooth employment to aggressive hiring and firing cycles.

The estimates of year fixed effects reported in Table 5 are of interest as well. The year dummy for 2005 was omitted from estimation, as it is the base year. The negative and large coefficients on the dummies for the recession years of 2008, 2009, and 2010 indicate a reduction in employment at credit unions and commercial banks beyond the effect of falling assets, since that term is already included in the model specification (2). Thus, employment is shrinking by more during those years than we would have predicted based on fluctuations in assets and employment in earlier years. An evaluation of the combined impact of the year fixed effect coefficients for 2008, 2009, and 2010 suggests that employment contracted by 7.5 per cent at commercial banks and 9 per cent at credit unions in excess of any reductions predicted from changes in assets over this period. This finding is surprising in light of the theorized greater stability in employment at credit unions, though arguably it may reflect the easier and more generous access to bailout funds for commercial banks compared to credit unions (see Klinedinst, 2012) and the heavier regulatory burden borne by credit unions compared to commercial banks (Ferri and Kalmi, 2014).

The four variations on specification (2) contain virtually identical coefficients on $\Delta \ln w$, also highly similar to those found in estimates of model (1) earlier. The coefficients are negative and highly significant for all variations in specifications (1) and (2). The negative signs are encouraging as factor demand theory dictates that an increase in wages should reduce labor demanded by firms. As such our findings are consistent with those of much earlier studies such as Taylor (1979), who finds a large, highly significant, negative coefficient for wages in modeling labor demand at US credit unions and Heshmati (2001) produces a similarly large, negative coefficient in his evaluation of labor demand at Swedish savings banks ${ }^{19}$.

Estimates of the magnitude for the coefficient on $\Delta \ln w$ are unexpected; the term for credit unions is twice as large as that for commercial banks. This suggests that given similarly sized firms with equal workforces, a one percent increase in wages predicts a downward employment adjustment at a credit union twice as large as the shift at a commercial bank. This finding is at odds

\footnotetext{
19 Note that this contradicts the empirical results of Burdín and Dean (2009) who find a significant negative coefficient for capitalist firms but a significant positive coefficient for worker cooperatives on the $\Delta \ln w$ term.
} 
with predictions derived from theory for labor-managed firms (which suggests that such firms tend to smooth employment, but forfeit some stability in wages.) However, as already noted, that theory is of limited relevance in understanding credit unions. Rather the finding points to our limited understanding of the forces driving behavior in credit unions and the need for additional theoretical work for such firms.

Previously we argued that wages can be treated as exogenous. An alternative view, which may provide an explanation for the unexpected pattern of coefficients on $\Delta \ln w$, is that wage and employment may be set simultaneously. If so, the pattern of coefficients might reflect simultaneous equation bias. A second potential reason for the estimated coefficients on $\Delta \ln w$ is division bias. The calculation of average wage, borrowed from the specification by Burdín and Dean (2009) and Pencavel, Pistaferri and Schivardi (2006), is obtained by dividing the total personnel expenses by total employment at each firm. Since employment is the dependent variable, errors in employment will therefore hard-wire a negative correlation between wage and employment, and hence make wage appear to have a negative demand elasticity. It is possible that there are differences in the extent of measurement errors between commercial banks and credit unions, thereby explaining the differences in estimated coefficients.

Controls for firm size are also highly significant at the 1 per cent level for both groups of firms when included, as exhibited by specification (2d). Although all are positive, thus predicting that larger firms increase employment by more than smaller firms do, there is substantial variation in the magnitude across firm types (see Table 5). The size of a credit union or a commercial bank influences employment growth, with large credit unions predicted to grow 3.7 per cent more, and medium credit unions predicted to grow 2.2 per cent more than small credit unions do annually. Size is more important for commercial banks than for credit unions. One potential explanation for the variation in coefficients and for the positive sign is that small IOFs and CUs are shrinking for much of the sample period. This could be due to possible economies of scale larger firms are able to enjoy, or may be illustrating the general consolidation trend in banking.

Some previous literature on employment adjustment, such as Kurtulus and Kruse (2016) for employee-owned firms, attempts to control for geographic factors through the introduction of regional unemployment rates. The high variation in unemployment rates across states during the 2008 financial crisis suggests that there could be differences in the experiences of financial firms based on where they were headquartered. When unemployment rates in the firm's state was added to specification (1) and (2) in multiple forms, it was never found to be close to being statistically significant. This suggests that shifts in the assets of firms are capturing more than just the macroeconomic climate, and that the state unemployment rate has a very limited effect once asset changes have been controlled for. There is also a data reporting issue, insofar as many firms (especially IOFs) have offices in numerous states, but are only able to report one state as their location. For these two reasons, we do not include the specifications for state unemployment in our results below. 
Several changes to the two primary model specifications help to provide clarity to employment adjustment when output shocks occur. We supplement the above two models with annual crosssections of the panel data to determine if there are large changes in the asset elasticity of employment over the period. We introduce time-lagged independent variables to determine if employment adjustment is inertial in response to asset changes, as some industries do exhibit lag. Finally, we compare the total assets variable in specification (2) with three alternate measures of bank output; total assets, fixed assets, loans, and deposits.

We supplement the two primary specifications with annual cross-sections of the balanced panel, estimated using OLS, to compare asset elasticity and wage elasticity of employment adjustment across years. This specification does not break out changes in assets into positive ones and negative shocks (see Table 6). Although the average employment elasticity of assets is lowest for credit unions (0.399), it is not much different from the average estimate for commercial banks (0.432). The estimated elasticity also fluctuates more than anticipated over the sample, but these movements are possible, given the significant changes in the US economic climate during that decade. A significance test of the null hypothesis that the coefficients on $\Delta \ln A$ are equal for a given type of firm across the entire sample period is rejected at the 1 per cent level for both commercial banks and credit unions. These findings indicate that the asset elasticity of employment differs across the period for commercial banks and credit unions. The cross-sections seem to suggest a downward trend in employment elasticity of wages for commercial banks over the decade, whereas for credit unions this remains mostly flat.

An analysis of the cross-section estimates fails to provide much support, if any, for the hypothesis that commercial banks and credit unions adjust employment differently for similar shocks in assets. When we test for coefficient equality for the two types of firms for each year individually, only four out of the eleven years of cross-sections had significant differences at the 5 per cent level. Another purpose of this specification was to provide more insight into potential employment elasticity differences between expansion and recession years, but no significant findings arose from these comparisons.

The replacement of total assets with alternative measures of output for financial institutions, namely non-fixed assets, loans, and deposits, generally supports the findings above (see Table 7). In particular, the use of non-fixed assets instead of total assets produces results that are statistically significant in the cases where total assets yielded significant results. However, it also indicates that credit unions are predicted to behave asymmetrically to shocks and that the employment adjustment reaction to negative output shocks by credit unions and commercial banks are significantly different.

We implement three robustness checks to increase confidence in our estimates of asset elasticity of employment at commercial banks and credit unions ${ }^{20}$. First, we validate our decision to exclude

20 The first two tests for robust results are not included in the tables of this paper, but are available from the authors upon request. 
firms with changes in assets that lie outside two standard deviations of annual means by comparing estimates of model (2) across the two samples. Although some variation occurs in the magnitude of coefficients, the differences in the results for the two samples are small. A similar comparison, performed on the panel excluding banks that engage in M\&A during the sample period, produces similarly significant results. We are therefore confident that these two exclusion rules do not qualitatively change our results.

The second robustness test confirms that the separate estimations of specification (2) for the different types of firms do not significantly alter results. We estimate specification (2) for the entire sample of firms, and include interaction terms for each type of firm with [ $\Delta \ln A^{*}$ Grow], [ $\Delta \ln A^{*}$ Shrink], and $[\Delta \ln w]$ to determine if any of the firm types are significantly different from the entire sample estimates. We find similar results to those discussed above.

We include estimations of specification (2) with one-year lags on the positive and negative asset changes as well as the change in wage (see Table 8 ). The three specifications estimated produce results that are highly similar to our earlier findings. Additionally, the time lagged specifications find statistically significant results in a few cases for which the estimates of model (2) without time lags found to be marginally insignificant $(p$-values $<0.1)$.

\section{Conclusions and implications}

This paper uses two main first-difference models to assess how commercial banks and credit unions adjust employment to shocks in output. We use these specifications to search for two types of asymmetries in the employment adjustment response to shocks in assets. We look for the presence of different reactions when assets increase compared to a decrease, within each type of institution. We also look at the relative asset elasticities of employment adjustment for different firms. We find significant evidence for two asymmetries; one "within" institution type and two "across" type of firm.

The employment adjustment response at commercial banks to a change in assets is significantly different for increases and decreases in those assets. This result suggests employment is "sticky" at commercial banks. However, the evidence that credit unions respond to asset shocks asymmetrically is weaker.

Credit unions adjust employment upwards in reaction to a positive change in assets by a smaller amount than commercial banks. Credit unions do not cut employment as much as IOFs do when a negative shock occurs to assets.

Thus, our findings indicate that commercial banks hire more aggressively, while credit unions prefer a more stable workforce. This difference in behavior is consistent with credit unions sharing multiple objectives-financial performance, serving the interests of its members or customers, and maintaining a corporate culture that values the contributions of their employees. The greater stability of credit union employment likely reflects the commitment of members to their firm and to its employees and the greater importance of "relationship lending". Insofar as credit unions are less inclined to lay workers off when business drops, they might be less aggressive in hiring workers during expansions. 
Evidence of enhanced employment resilience of organizational forms alternative to IOFs is relatively sparse. The earliest evidence is for worker cooperatives, notably US plywood firms (Craig and Pencavel, 1992), Italy (Pencavel, Pistaferri and Schivardi, 2006) and for firms in Uruguay (Burdín and Dean, 2009). More recently, Kurtulus and Kruse (2016) present new evidence that links employee ownership in US firms with increased employment stability. Our study complements these previous studies. Moreover, our findings are for a significant case-credit unions in the US are often reported (e.g., by the World Council on Credit Unions) as having one of the highest market penetration rates in the world (more than 40 per cent). More generally, our results provide an important complement to these other findings for workers cooperatives and firms with employee ownership and thus expand the range of alternative institutional arrangements for which evidence exists for greater employment resiliency compared to IOFs.

Our findings, as does work by others including Klinedinst (2012) and Birchall (2013) suggest that credit unions and cooperatives have been more resilient during the latest recession. They also contribute to the more general literature concerning the economic potential of credit unions and cooperatives compared to IOFs. For example, for the US, Klinedinst (2012: 4) finds that, compared to commercial banks, credit unions “.... are often estimated to have a better return on assets and... higher efficiency in that they control more assets per dollar spent on salaries than commercial and savings banks....". Outside the US other firm level studies that find positive effects of cooperatives compared to other organizational forms include Ferri, Kalmi and Karola (2014) and Mäkinen and Jones (2015). Also, econometric case study evidence for Finnish co-operative banks (Jones, Kalmi and Kauhanen, 2012) is consistent with the hypothesis that employee members in cooperative banks are apt to have increased loyalty and lower turnover and that, in turn, this may lead to extensive training of the workforce and more accumulation of human capital. In addition, our findings complement those of others who have identified broader benefits of US credit unions. For example, Feinberg (2001: 560) examines the impact of the competitive discipline provided by credit unions on consumer credit rates offered by banks and finds a "... significant role for credit unions in disciplining the exercise of market power by banks". In sum, our findings may contribute to the on-going policy debates surrounding the varying roles of different types of US financial institutions in the future.

Finally our findings may have more general implications for what is often a very pessimistic view concerning the economic potential of all kinds of cooperatives. Together with other theoretical and empirical work, these findings suggest further support for what has been characterized as "a new view of cooperatives" (Jones and Kalmi, 2015). The results reported in this paper help to bolster this alternative perspective on credit unions and cooperatives of all kinds. Jones, Kalmi and Kauhanen (2012) show that cooperative ownership structures favors human capital accumulation and improve worker outcomes (notably wages) for employee members without adverse effects to organizational performance. More broadly, the "new view" on cooperatives may help to identify their proper role_-alongside with other cooperatives_-in providing a valuable contribution to a piecemeal evolution towards a more democratic and stable economic order. 


\section{Appendix}

Table 1. List of variable definitions

\section{Variables: Definitions:}

$\Delta \ln E_{i t} \quad$ Annual change in (natural $\log$ ) of full-time equivalent employment $=\ln E_{i t}-\ln E_{i t-1}$

$\Delta \ln A_{i t} \quad$ Annual change in (natural $\log$ ) of real total assets $=\ln A_{i t}-\ln A_{i t-1}$. Inflation-adjusted using GDP deflator with base year 2005 .

$\Delta \ln N_{i t} \quad$ Annual change in (natural $\log$ ) of real non-fixed assets $=\ln N_{i t}-\ln N_{i t-1} . N$ is computed from Total Assets - Fixed Assets. Inflation-adjusted using GDP deflator with base year 2005.

$\begin{array}{ll}\Delta \ln L_{i t} & \text { Annual change in } \\ \text { with base year } 2005\end{array}$

$\Delta \ln D_{i t} \quad$ Annual change in (natural $\log$ ) of real deposits $=\ln D_{i t}-\ln D_{i t-1}$. Inflation-adjusted using GDP deflator with base year 2005 .

$\Delta \ln w_{i t} \quad$ Annual change in (natural $\log$ ) of real wages $=\ln w_{i t}-\ln w_{i t-1} \cdot w$ is computed by dividing total personnel expenses by total employment. Inflation-adjusted using CPI with base year 2005.

Shrink $_{i t} \quad$ Dummy variable $=1$ if real total assets at firm $i$ are less than the previous year and is otherwise 0

Small $_{i} \quad$ Dummy variable $=1$ if firm $i$ employs between $10-99$ employees in 2005 and is otherwise 0

Medium $_{i} \quad$ Dummy variable $=1$ if firm $i$ employs between $100-249$ employees in 2005 and is otherwise 0

Large $_{i} \quad$ Dummy variable $=1$ if firm $i$ employs between more than 250 employees in 2005 and is otherwise 0

$\mathrm{CB}_{i} \quad$ Dummy variable $=1$ if firm $i$ is a commercial bank and is otherwise 0

$\mathrm{CU}_{i} \quad$ Dummy variable $=1$ if firm $i$ is a credit union and is otherwise 0

Note: Year dummies are also included with base year 2005 .

\section{Table 2. Summary of firms in sample}

\begin{tabular}{lrr}
\hline Measure: & CB & CU \\
\hline \# firms in balanced panel & 4,699 & 2,146 \\
\# firms with $\Delta \ln A_{i t}>2$ std. dev. & 164 & 80 \\
\# firms merged from 1999-2010 & 543 & $n / a$ \\
Small & 3656 & 1727 \\
Medium & 722 & 311 \\
Large & 321 & 108 \\
\hline
\end{tabular}

Small $=10-99$ employees; Medium $=100-249$ employees; Large $>250$ employees

${ }^{*}$ signifies significance at $5 \%$ level; ${ }^{* *}$ signifies significance at $1 \%$ level. 
Table 3. Descriptive statistics

\begin{tabular}{ccccccc}
\hline \multirow{2}{*}{ Year } & \multicolumn{2}{c}{ Employment (FTE) } & \multicolumn{4}{c}{ Real Assets (Thousands \$) } \\
\cline { 2 - 6 } & CB & CU & CB & CU & CB & CU \\
\hline I. Mean sample values, by year & & & & & \\
1999 & 183.83 & 58.00 & 713378 & 160611 & 46.51 & 42.02 \\
\hline 2000 & 191.91 & 61.15 & 768332 & 170517 & 47.23 & 42.52 \\
\hline 2001 & 206.03 & 64.74 & 850224 & 193725 & 47.68 & 43.52 \\
\hline 2002 & 214.82 & 67.44 & 920901 & 213177 & 49.67 & 45.16 \\
\hline 2003 & 207.42 & 71.15 & 931899 & 232190 & 50.87 & 46.46 \\
\hline 2004 & 207.79 & 73.89 & 882529 & 243243 & 51.35 & 47.40 \\
2005 & 240.00 & 77.01 & 1036757 & 251668 & 51.78 & 47.37 \\
\hline 2006 & 240.98 & 80.01 & 1184911 & 256559 & 52.06 & 47.70 \\
\hline 2007 & 304.67 & 80.29 & 1560728 & 249088 & 52.25 & 47.86 \\
\hline 2008 & 308.94 & 86.43 & 1719314 & 282053 & 51.92 & 48.12 \\
\hline 2009 & 313.41 & 85.61 & 1730260 & 302010 & 53.63 & 49.60 \\
\hline 2010 & 290.13 & 88.30 & 1625987 & 320677 & 54.04 & 50.30 \\
\hline
\end{tabular}

II. Median sample values, by year

\begin{tabular}{|ccccccc|}
\hline 1999 & 34.00 & 29.00 & 99710 & 67903 & 44.50 & 40.58 \\
\hline 2000 & 36.00 & 30.50 & 106764 & 70778 & 45.08 & 41.05 \\
\hline 2001 & 37.00 & 31.50 & 113028 & 76663 & 45.72 & 42.16 \\
\hline 2002 & 39.00 & 33.00 & 121553 & 81667 & 47.46 & 43.50 \\
\hline 2003 & 40.00 & 34.00 & 127113 & 86035 & 48.37 & 44.61 \\
\hline 2004 & 42.00 & 35.50 & 131572 & 89028 & 48.89 & 45.67 \\
\hline 2005 & 43.00 & 37.00 & 137069 & 87691 & 48.97 & 45.62 \\
\hline 2006 & 45.00 & 37.50 & 143335 & 87799 & 49.31 & 45.88 \\
\hline 2007 & 46.00 & 39.00 & 147293 & 91383 & 49.56 & 45.90 \\
\hline 2008 & 47.00 & 40.00 & 153986 & 95754 & 49.44 & 46.35 \\
\hline 2009 & 47.00 & 40.00 & 160850 & 102159 & 50.77 & 47.64 \\
\hline 2010 & 47.00 & 41.00 & 162364 & 105508 & 51.33 & 48.49 \\
\hline Overall Mean & 242.56 & 74.45 & 1161052 & 239339 & 50.75 & 46.49 \\
\hline Overall Median & 42.00 & 35.50 & 130887 & 86034 & 48.26 & 44.79 \\
\hline
\end{tabular}


Table 4. Estimates of primary specification (1)

\begin{tabular}{|c|c|c|c|c|c|c|}
\hline \multirow{2}{*}{$\Delta \ln \mathrm{E}$} & \multicolumn{2}{|c|}{ (1a) } & \multicolumn{2}{|c|}{ (1b) } & \multicolumn{2}{|c|}{ (1c) } \\
\hline & CB & CU & CB & $\mathbf{C U}$ & CB & CU \\
\hline \multirow[t]{2}{*}{$\Delta \ln A$} & 0.427 & 0.401 & 0.367 & 0.257 & 0.346 & 0.284 \\
\hline & $(0.008)^{* *}$ & $(0.010)^{* *}$ & $(0.008)^{* *}$ & $(0.010)^{* *}$ & $(0.009)^{* *}$ & $(0.012)^{* *}$ \\
\hline \multirow[t]{2}{*}{$\Delta \ln w$} & -0.253 & -0.549 & -0.255 & -0.561 & -0.257 & -0.561 \\
\hline & $(0.022)^{* *}$ & $(0.044)^{* *}$ & $(0.022)^{* *}$ & $(0.046)^{* *}$ & $(0.022)^{* *}$ & $(0.047)^{* *}$ \\
\hline \multirow[t]{2}{*}{2000} & & & & & -0.001 & 0.008 \\
\hline & & & & & $(0.002)$ & $(0.002)^{* *}$ \\
\hline \multirow[t]{2}{*}{2001} & & & & & 0.005 & -0.003 \\
\hline & & & & & $(0.002)^{*}$ & $(0.003)$ \\
\hline \multirow[t]{2}{*}{2002} & & & & & 0.008 & 0.008 \\
\hline & & & & & $(0.002)^{* *}$ & $(0.003)^{*}$ \\
\hline \multirow[t]{2}{*}{2003} & & & & & 0.002 & 0.004 \\
\hline & & & & & $(0.002)$ & $(0.003)$ \\
\hline \multirow[t]{2}{*}{2004} & & & & & -0.003 & 0.003 \\
\hline & & & & & $(0.002)$ & $(0.003)$ \\
\hline \multirow[t]{2}{*}{2005} & & & & & -0.003 & 0.004 \\
\hline & & & & & $(0.002)$ & $(0.002)$ \\
\hline \multirow[t]{2}{*}{2006} & & & & & -0.007 & 0.000 \\
\hline & & & & & $(0.002)^{* *}$ & $(0.002)$ \\
\hline \multirow[t]{2}{*}{2007} & & & & & -0.025 & -0.024 \\
\hline & & & & & $(0.002)^{* *}$ & $(0.002)^{* *}$ \\
\hline \multirow[t]{2}{*}{2008} & & & & & -0.030 & -0.034 \\
\hline & & & & & $(0.002)^{* *}$ & $(0.003)^{* *}$ \\
\hline \multirow[t]{2}{*}{2009} & & & & & -0.023 & -0.034 \\
\hline & & & & & $(0.002)^{* *}$ & $(0.002)^{* *}$ \\
\hline \multicolumn{7}{|l|}{2010} \\
\hline \multirow[t]{2}{*}{ Constant } & 0.012 & 0.012 & 0.015 & 0.015 & 0.021 & 0.021 \\
\hline & $(0.000)^{* *}$ & $(0.000)^{* *}$ & $(0.000)^{* *}$ & $(0.000)^{* *}$ & $(0.001)^{* *}$ & $(0.001)^{* *}$ \\
\hline Fixed-Effects & $\mathrm{N}$ & $\mathrm{N}$ & Y & Y & Y & Y \\
\hline$N$ & 77,887 & 77,887 & 77,887 & 77,887 & 77,887 & 77,887 \\
\hline
\end{tabular}

* signifies significance at $5 \%$ level; ${ }^{* *}$ signifies significance at $1 \%$ level. Standard errors are shown in parentheses. 
Table 5. Estimates of primary specification (2)

\begin{tabular}{|c|c|c|c|c|c|c|c|c|}
\hline \multirow{2}{*}{$\Delta \ln \mathrm{E}$} & \multicolumn{2}{|c|}{$(2 a)$} & \multicolumn{2}{|c|}{$(2 b)$} & \multicolumn{2}{|c|}{ (2c) } & \multicolumn{2}{|c|}{$(2 d)$} \\
\hline & CB & $\mathrm{CU}$ & CB & $\mathrm{CU}$ & CB & $\mathrm{CU}$ & CB & $\mathrm{CU}$ \\
\hline \multirow[t]{2}{*}{$\Delta \ln A^{*}$ Grow } & 0.491 & 0.498 & 0.466 & 0.247 & 0.449 & 0.288 & 0.453 & 0.289 \\
\hline & $(0.011)^{* *}$ & $(0.012)^{* *}$ & $(0.012)^{* *}$ & $(0.013)^{* *}$ & $(0.012)^{* *}$ & $(0.016)^{* *}$ & $(0.012)^{* *}$ & $(0.016)^{* *}$ \\
\hline \multirow{2}{*}{$\Delta \ln A^{*}$ Shrink } & 0.383 & 0.307 & 0.340 & 0.244 & 0.295 & 0.223 & 0.289 & 0.221 \\
\hline & $(0.027)^{* *}$ & $(0.032)^{* *}$ & $(0.027)^{* *}$ & $(0.035)^{* *}$ & $(0.026)^{* *}$ & $(0.034)^{* *}$ & $(0.026)^{* *}$ & $(0.034)^{* *}$ \\
\hline \multirow[t]{2}{*}{$\Delta \ln w$} & -0.251 & -0.551 & -0.254 & -0.561 & -0.256 & -0.561 & -0.256 & -0.560 \\
\hline & $(0.022)^{* *}$ & $(0.045)^{* *}$ & $(0.022)^{* *}$ & $(0.046)^{* *}$ & $(0.022)^{* *}$ & $(0.047)^{* *}$ & $(0.022)^{* *}$ & $(0.046)^{* *}$ \\
\hline \multirow[t]{2}{*}{ Shrink } & 0.006 & 0.014 & 0.015 & -0.002 & 0.014 & -0.003 & 0.014 & -0.003 \\
\hline & $(0.001)^{* *}$ & $(0.002)^{* *}$ & $(0.001)^{* *}$ & $(0.002)$ & $(0.001)^{* *}$ & $(0.002)$ & $(0.001)^{* *}$ & $(0.002)$ \\
\hline \multirow[t]{2}{*}{ Medium } & & & & & & & 0.039 & 0.022 \\
\hline & & & & & & & $(0.005)^{* *}$ & $(0.004)^{* *}$ \\
\hline \multirow[t]{2}{*}{ Large } & & & & & & & 0.068 & 0.037 \\
\hline & & & & & & & $(0.008)^{* *}$ & $(0.007)^{* *}$ \\
\hline \multirow[t]{2}{*}{2000} & & & & & -0.000 & 0.008 & 0.002 & 0.009 \\
\hline & & & & & $(0.002)$ & $(0.002)^{* *}$ & $(0.002)$ & $(0.002)^{* *}$ \\
\hline \multirow[t]{2}{*}{2001} & & & & & 0.005 & -0.003 & 0.007 & -0.002 \\
\hline & & & & & $(0.002)^{* *}$ & $(0.003)$ & $(0.002)^{* *}$ & $(0.003)$ \\
\hline \multirow[t]{2}{*}{2002} & & & & & 0.009 & 0.008 & 0.010 & 0.008 \\
\hline & & & & & $(0.002)^{* *}$ & $(0.003)^{*}$ & $(0.002)^{* *}$ & $(0.003)^{*}$ \\
\hline \multirow[t]{2}{*}{2003} & & & & & 0.003 & 0.004 & 0.004 & 0.005 \\
\hline & & & & & $(0.002)$ & $(0.003)$ & $(0.002)^{*}$ & $(0.003)$ \\
\hline \multirow[t]{2}{*}{2004} & & & & & -0.002 & 0.003 & -0.002 & 0.004 \\
\hline & & & & & $(0.002)$ & $(0.003)$ & $(0.002)$ & $(0.003)$ \\
\hline \multicolumn{9}{|l|}{2005} \\
\hline \multirow[t]{2}{*}{2006} & & & & & -0.002 & 0.004 & -0.003 & 0.003 \\
\hline & & & & & $(0.002)$ & $(0.002)$ & $(0.002)$ & $(0.002)$ \\
\hline \multirow[t]{2}{*}{2007} & & & & & -0.006 & 0.000 & -0.007 & -0.000 \\
\hline & & & & & $(0.002)^{* *}$ & $(0.002)$ & $(0.002)^{* *}$ & $(0.002)$ \\
\hline \multirow[t]{2}{*}{2008} & & & & & -0.025 & -0.024 & -0.026 & -0.025 \\
\hline & & & & & $(0.002)^{* *}$ & $(0.002)^{* *}$ & $(0.002)^{* *}$ & $(0.002)^{* *}$ \\
\hline \multirow[t]{2}{*}{2009} & & & & & -0.029 & -0.034 & -0.030 & -0.035 \\
\hline & & & & & $(0.002)^{* *}$ & $(0.003)^{* *}$ & $(0.002)^{* *}$ & $(0.003)^{* *}$ \\
\hline \multirow[t]{2}{*}{2010} & & & & & -0.023 & -0.034 & -0.024 & -0.035 \\
\hline & & & & & $(0.002)^{* *}$ & $(0.002)^{* *}$ & $(0.002)^{* *}$ & $(0.002)^{* *}$ \\
\hline \multirow[t]{2}{*}{ Constant } & 0.004 & 0.004 & 0.008 & 0.008 & 0.013 & 0.013 & 0.003 & 0.003 \\
\hline & $(0.001)^{* *}$ & $(0.001)^{* *}$ & $(0.001)^{* *}$ & $(0.001)^{* *}$ & $(0.001)^{* *}$ & $(0.001)^{* *}$ & $(0.001)$ & $(0.001)$ \\
\hline Fixed-Effects & $\mathrm{N}$ & $\mathrm{N}$ & $\mathrm{Y}$ & $\mathrm{Y}$ & $\mathrm{Y}$ & $\mathrm{Y}$ & $\mathrm{Y}$ & $\mathrm{Y}$ \\
\hline$N$ (firm years) & 50,036 & 22,726 & 50,036 & 22,726 & 50,036 & 22,726 & 50,036 & 22,726 \\
\hline
\end{tabular}

${ }^{*}$ signifies significance at $5 \%$ level; ${ }^{* *}$ signifies significance at $1 \%$ level. Standard errors are shown in parentheses. 
Table 6. Cross-sectional regression estimates: OLS estimates of $\Delta \ln \mathrm{E}$

\begin{tabular}{|c|c|c|c|c|c|c|c|c|c|c|c|c|}
\hline & $\Delta \ln E$ & 2000 & 2001 & 2002 & 2003 & 2004 & 2005 & 2006 & 2007 & 2008 & 2009 & 2010 \\
\hline \multirow{4}{*}{$\mathrm{CB}$} & \multirow[t]{2}{*}{$\Delta \ln A$} & 0.501 & 0.482 & 0.479 & 0.444 & 0.437 & 0.419 & 0.434 & 0.400 & 0.345 & 0.425 & 0.386 \\
\hline & & $(0.018)^{* *}$ & $(0.015)^{* *}$ & $(0.015)^{* *}$ & $(0.017)^{* *}$ & $(0.017)^{* *}$ & $(0.016)^{* *}$ & $(0.018)^{* *}$ & $(0.018)^{* *}$ & $(0.016)^{* *}$ & $(0.015)^{* *}$ & $(0.015)^{* *}$ \\
\hline & \multirow[t]{2}{*}{$\Delta \ln w$} & -0.354 & -0.409 & -0.254 & -0.305 & -0.311 & -0.244 & -0.312 & -0.254 & -0.212 & -0.198 & -0.118 \\
\hline & & $(0.011)^{* *}$ & $(0.011)^{* *}$ & $(0.009)^{* *}$ & $(0.011)^{* *}$ & $(0.010)^{* *}$ & $(0.009)^{* *}$ & $(0.011)^{* *}$ & $(0.010)^{* *}$ & $(0.009)^{* *}$ & $(0.009)^{* *}$ & $(0.007)^{* *}$ \\
\hline \multirow{4}{*}{$\mathrm{CU}$} & $\Delta \ln A$ & 0.482 & 0.395 & 0.396 & 0.453 & 0.479 & 0.347 & 0.325 & 0.358 & 0.387 & 0.328 & 0.443 \\
\hline & & $(0.029)^{* *}$ & $(0.026)^{* *}$ & $(0.027)^{* *}$ & $(0.031)^{* *}$ & $(0.032)^{* *}$ & $(0.027)^{* *}$ & $(0.025)^{* *}$ & $(0.026)^{* *}$ & $(0.025)^{* *}$ & $(0.024)^{* *}$ & $(0.025)^{* *}$ \\
\hline & \multirow[t]{2}{*}{$\Delta \ln w$} & -0.683 & -0.687 & -0.454 & -0.481 & -0.554 & -0.504 & -0.603 & -0.587 & -0.647 & -0.530 & -0.413 \\
\hline & & $(0.015)^{* *}$ & $(0.015)^{* *}$ & $(0.015)^{* *}$ & $(0.015)^{* *}$ & $(0.016)^{* *}$ & $(0.016)^{* *}$ & $(0.016)^{* *}$ & $(0.016)^{* *}$ & $(0.015)^{* *}$ & $(0.016)^{* *}$ & $(0.015)^{* *}$ \\
\hline
\end{tabular}

* signifies significance at $5 \%$ level; ${ }^{* *}$ signifies significance at $1 \%$ level. Standard errors are shown in parentheses.

Table 7. Auxiliary estimates of primary specification (2) alternative output variables

(2d)

(3)

(4)

(5)

\begin{tabular}{|c|c|c|c|c|c|c|c|c|}
\hline$\Delta \ln \mathrm{E}$ & CB & $\mathrm{CU}$ & CB & $\mathbf{C U}$ & CB & $\mathbf{C U}$ & CB & $\mathbf{C U}$ \\
\hline \multirow[t]{2}{*}{$\Delta \ln A^{*}$ Grow } & 0.453 & 0.289 & & & & & & \\
\hline & $(0.012)^{* *}$ & $(0.016)^{* *}$ & & & & & & \\
\hline \multirow[t]{2}{*}{$\Delta \ln A^{*}$ Shrink } & 0.289 & 0.221 & & & & & & \\
\hline & $(0.026)^{* *}$ & $(0.034)^{* *}$ & & & & & & \\
\hline \multirow[t]{2}{*}{$\Delta \ln N^{*}$ Grow } & & & 0.423 & 0.239 & & & & \\
\hline & & & $(0.012)^{* *}$ & $(0.015)^{* *}$ & & & & \\
\hline \multirow[t]{2}{*}{$\Delta \ln N^{*}$ Shrink } & & & 0.241 & 0.092 & & & & \\
\hline & & & $(0.025)^{* *}$ & $(0.033)^{* *}$ & & & & \\
\hline \multirow[t]{2}{*}{$\Delta \ln L^{*}$ Grow } & & & & & 0.290 & 0.181 & & \\
\hline & & & & & $(0.011)^{* *}$ & $(0.010)^{* *}$ & & \\
\hline \multirow[t]{2}{*}{$\Delta \ln L^{*}$ Shrink } & & & & & 0.126 & 0.176 & & \\
\hline & & & & & $(0.014)^{* *}$ & $(0.014)^{* *}$ & & \\
\hline \multirow[t]{2}{*}{$\Delta \ln D^{*}$ Grow } & & & & & & & 0.308 & 0.253 \\
\hline & & & & & & & $(0.015)^{* *}$ & $(0.015)^{* *}$ \\
\hline \multirow[t]{2}{*}{$\Delta \ln D^{*}$ Shrink } & & & & & & & 0.083 & 0.086 \\
\hline & & & & & & & $(0.020)^{* *}$ & $(0.029)^{* *}$ \\
\hline \multirow[t]{2}{*}{$\Delta \ln w$} & -0.256 & -0.560 & -0.257 & -0.562 & -0.268 & -0.564 & -0.259 & -0.561 \\
\hline & $(0.022)^{* *}$ & $(0.046)^{* *}$ & $(0.022)^{* *}$ & $(0.046)^{* *}$ & $(0.023)^{* *}$ & $(0.046)^{* *}$ & $(0.022)^{* *}$ & $(0.047)^{* *}$ \\
\hline \multirow[t]{2}{*}{ Shrink } & 0.014 & -0.003 & 0.010 & -0.010 & -0.013 & -0.016 & -0.006 & -0.010 \\
\hline & $(0.001)^{* *}$ & $(0.002)$ & $(0.001)^{* *}$ & $(0.002)^{* *}$ & $(0.001)^{* *}$ & $(0.001)^{* *}$ & $(0.001)^{* *}$ & $(0.002)^{* *}$ \\
\hline
\end{tabular}


Table 7. Continued

(2d)

(3)

(4)

(5)

\begin{tabular}{lcccccccccc}
\hline$\Delta$ ln E & CB & CU & CB & CU & CB & CU & CB & CU \\
\hline Medium & 0.039 & 0.022 & 0.040 & 0.022 & 0.038 & 0.024 & 0.038 & 0.022 \\
& $(0.005)^{* *}$ & $(0.004)^{* *}$ & $(0.005)^{* *}$ & $(0.004)^{* *}$ & $(0.005)^{* *}$ & $(0.004)^{* *}$ & $(0.005)^{* *}$ & $(0.004)^{* *}$ \\
\hline Large & 0.068 & 0.037 & 0.070 & 0.037 & 0.066 & 0.038 & 0.065 & 0.035 \\
& $(0.008)^{* *}$ & $(0.007)^{* *}$ & $(0.008)^{* *}$ & $(0.007)^{* *}$ & $(0.008)^{* *}$ & $(0.006)^{* *}$ & $(0.009)^{* *}$ & $(0.007)^{* *}$ \\
2000 & 0.002 & 0.009 & 0.003 & 0.010 & -0.001 & 0.009 & 0.005 & 0.009 \\
& $(0.002)$ & $(0.002)^{* *}$ & $(0.002)$ & $(0.002)^{* *}$ & $(0.002)$ & $(0.002)^{* *}$ & $(0.002)^{* *}$ & $(0.002)^{* *}$ \\
2001 & 0.007 & -0.002 & 0.008 & 0.001 & 0.015 & 0.023 & 0.008 & -0.003 \\
& $(0.002)^{* *}$ & $(0.003)$ & $(0.002)^{* *}$ & $(0.003)$ & $(0.002)^{* *}$ & $(0.003)^{* *}$ & $(0.002)^{* *}$ & $(0.003)$ \\
2002 & 0.010 & 0.008 & 0.010 & 0.010 & 0.016 & 0.026 & 0.013 & 0.008 \\
& $(0.002)^{* *}$ & $(0.003)^{*}$ & $(0.002)^{* *}$ & $(0.003)^{* *}$ & $(0.002)^{* *}$ & $(0.003)^{* *}$ & $(0.002)^{* *}$ & $(0.003)^{*}$ \\
2003 & 0.004 & 0.005 & 0.004 & 0.006 & 0.009 & 0.016 & 0.006 & 0.005 \\
& $(0.002)^{*}$ & $(0.003)$ & $(0.002)^{*}$ & $(0.003)^{*}$ & $(0.002)^{* *}$ & $(0.003)^{* *}$ & $(0.002)^{* *}$ & $(0.003)$ \\
2004 & -0.002 & 0.004 & -0.002 & 0.004 & -0.005 & 0.006 & 0.000 & 0.004 & $(0.002)$ & $(0.003)$
\end{tabular}

2005

\begin{tabular}{|c|c|c|c|c|c|c|c|c|}
\hline \multirow[t]{2}{*}{2006} & -0.003 & 0.003 & -0.003 & 0.003 & -0.002 & 0.007 & -0.003 & 0.002 \\
\hline & $(0.002)$ & $(0.002)$ & $(0.002)$ & $(0.002)$ & $(0.002)$ & $(0.002)^{* *}$ & $(0.002)$ & $(0.002)$ \\
\hline \multirow[t]{2}{*}{2007} & -0.007 & -0.000 & -0.007 & -0.000 & -0.007 & 0.008 & -0.006 & -0.001 \\
\hline & $(0.002)^{* *}$ & $(0.002)$ & $(0.002)^{* *}$ & $(0.002)$ & $(0.002)^{* *}$ & $(0.002)^{* *}$ & $(0.002)^{* *}$ & $(0.002)$ \\
\hline \multirow[t]{2}{*}{2008} & -0.026 & -0.025 & -0.026 & -0.024 & -0.023 & -0.014 & -0.024 & -0.026 \\
\hline & $(0.002)^{* *}$ & $(0.002)^{* *}$ & $(0.002)^{* *}$ & $(0.002)^{* *}$ & $(0.002)^{* *}$ & $(0.002)^{* *}$ & $(0.002)^{* *}$ & $(0.002)^{* *}$ \\
\hline \multirow[t]{2}{*}{2009} & -0.030 & -0.035 & -0.031 & -0.033 & -0.019 & -0.012 & -0.037 & -0.037 \\
\hline & $(0.002)^{* *}$ & $(0.003)^{* *}$ & $(0.002)^{* *}$ & $(0.003)^{* *}$ & $(0.002)^{* *}$ & $(0.003)^{* *}$ & $(0.002)^{* *}$ & $(0.003)^{* *}$ \\
\hline \multirow[t]{2}{*}{2010} & -0.024 & -0.035 & -0.025 & -0.035 & -0.015 & -0.019 & -0.030 & -0.038 \\
\hline & $(0.002)^{* *}$ & $(0.002)^{* *}$ & $(0.002)^{* *}$ & $(0.002)^{* *}$ & $(0.002)^{* *}$ & $(0.002)^{* *}$ & $(0.002)^{* *}$ & $(0.002)^{* *}$ \\
\hline \multirow[t]{2}{*}{ Constant } & 0.003 & 0.003 & 0.005 & 0.005 & 0.011 & 0.011 & 0.010 & 0.010 \\
\hline & $(0.001)$ & $(0.001)$ & $(0.001)^{* *}$ & $(0.001)^{* *}$ & $(0.002)^{* *}$ & $(0.002)^{* *}$ & $(0.001)^{* *}$ & $(0.001)^{* *}$ \\
\hline Fixed-Effects & $\mathrm{Y}$ & Y & Y & $\mathrm{Y}$ & $\mathrm{Y}$ & Y & $\mathrm{Y}$ & $\mathrm{Y}$ \\
\hline$N$ (firm years) & 50,036 & 22,726 & 50,036 & 22,726 & 50,036 & 22,726 & 50,036 & 22,726 \\
\hline
\end{tabular}

${ }^{*}$ signifies significance at $5 \%$ level; ** signifies significance at $1 \%$ level. Standard errors are shown in parentheses. 
Table 8. Auxiliary estimates of primary specification (2): lagged change in assets and wages

\begin{tabular}{|c|c|c|c|c|c|c|}
\hline \multirow[b]{2}{*}{$\Delta \ln E$} & \multicolumn{2}{|c|}{ (6) } & \multicolumn{2}{|c|}{ (7) } & \multicolumn{2}{|c|}{ (8) } \\
\hline & CB & CU & CB & $\mathbf{C U}$ & CB & CU \\
\hline \multirow[t]{2}{*}{$\Delta \ln A^{*}$ Grow } & 0.461 & 0.310 & & & 0.425 & 0.258 \\
\hline & $(0.014)^{* *}$ & $(0.022)^{* *}$ & & & $(0.013)^{* *}$ & $(0.017)^{* *}$ \\
\hline \multirow[t]{2}{*}[\Delta\operatorname{ln}A^{*}\text{Grow}]{$_{t-1}$} & & & 0.050 & 0.072 & 0.064 & 0.105 \\
\hline & & & $(0.008)^{* *}$ & $(0.015)^{* *}$ & $(0.009)^{* *}$ & $(0.013)^{* *}$ \\
\hline \multirow[t]{2}{*}{$\Delta \ln A^{*}$ Shrink } & 0.270 & 0.201 & & & 0.271 & 0.194 \\
\hline & $(0.026)^{* *}$ & $(0.046)^{* *}$ & & & $(0.025)^{* *}$ & $(0.033)^{* *}$ \\
\hline \multirow[t]{2}{*}[\Delta\operatorname{ln}A^{*}\text{Shrink}]{$_{t-1}$} & & & -0.017 & 0.169 & 0.001 & 0.100 \\
\hline & & & $(0.044)$ & $(0.043)^{* *}$ & $(0.038)$ & $(0.044)^{*}$ \\
\hline \multirow[t]{2}{*}{$\Delta \ln w$} & & & & & -0.270 & -0.591 \\
\hline & & & & & $(0.024)^{* *}$ & $(0.052)^{* *}$ \\
\hline \multirow[t]{2}{*}{$\Delta \ln w_{t-1}$} & 0.055 & 0.158 & 0.058 & 0.157 & -0.053 & -0.091 \\
\hline & $(0.008)^{* *}$ & $(0.028)^{* *}$ & $(0.008)^{* *}$ & $(0.028)^{* *}$ & $(0.009)^{* *}$ & $(0.012)^{* *}$ \\
\hline \multirow[t]{2}{*}{ Shrink } & 0.014 & -0.001 & & & 0.012 & -0.002 \\
\hline & $(0.001)^{* *}$ & $(0.002)$ & & & $(0.001)^{* *}$ & $(0.002)$ \\
\hline \multirow[t]{2}{*}{ Shrink $_{t-1}$} & & & -0.012 & -0.002 & -0.009 & -0.002 \\
\hline & & & $(0.002)^{* *}$ & $(0.002)$ & $(0.002)^{* *}$ & $(0.002)$ \\
\hline \multirow[t]{2}{*}{ Medium } & 0.045 & 0.032 & 0.042 & 0.031 & 0.040 & 0.020 \\
\hline & $(0.005)^{* *}$ & $(0.008)^{* *}$ & $(0.006)^{* *}$ & $(0.008)^{* *}$ & $(0.005)^{* *}$ & $(0.004)^{* *}$ \\
\hline \multirow[t]{2}{*}{ Large } & 0.078 & 0.046 & 0.068 & 0.039 & 0.066 & 0.029 \\
\hline & $(0.010)^{* *}$ & $(0.011)^{* *}$ & $(0.010)^{* *}$ & $(0.011)^{* *}$ & $(0.009)^{* *}$ & $(0.007)^{* *}$ \\
\hline \multirow[t]{2}{*}{2000} & 0.000 & 0.000 & 0.000 & 0.000 & 0.000 & 0.000 \\
\hline & $(0.000)$ & $(0.000)$ & $(0.000)$ & $(0.000)$ & $(0.000)$ & $(0.000)$ \\
\hline \multirow[t]{2}{*}{2001} & 0.005 & -0.015 & 0.013 & 0.012 & 0.005 & -0.000 \\
\hline & $(0.002)^{*}$ & $(0.003)^{* *}$ & $(0.002)^{* *}$ & $(0.003)^{* *}$ & $(0.002)^{* *}$ & $(0.003)$ \\
\hline \multirow[t]{2}{*}{2002} & 0.002 & -0.012 & 0.007 & 0.002 & 0.008 & 0.003 \\
\hline & $(0.002)$ & $(0.003)^{* *}$ & $(0.002)^{* *}$ & $(0.003)$ & $(0.002)^{* *}$ & $(0.003)$ \\
\hline \multirow[t]{2}{*}{2003} & -0.002 & -0.014 & -0.003 & -0.003 & 0.003 & 0.003 \\
\hline & $(0.002)$ & $(0.003)^{* *}$ & $(0.002)$ & $(0.003)$ & $(0.002)^{*}$ & $(0.003)$ \\
\hline \multirow[t]{2}{*}{2004} & -0.004 & -0.008 & -0.005 & -0.007 & -0.002 & 0.001 \\
\hline & $(0.002)^{*}$ & $(0.003)^{* *}$ & $(0.002)^{* *}$ & $(0.003)^{* *}$ & $(0.002)$ & $(0.003)$ \\
\hline \multicolumn{7}{|l|}{2005} \\
\hline \multirow[t]{2}{*}{2006} & -0.003 & 0.002 & -0.005 & 0.003 & -0.003 & 0.004 \\
\hline & $(0.002)$ & $(0.003)$ & $(0.002)^{*}$ & $(0.003)$ & $(0.002)$ & $(0.002)$ \\
\hline \multirow[t]{2}{*}{2007} & -0.008 & -0.002 & -0.010 & 0.005 & -0.007 & 0.002 \\
\hline & $(0.002)^{* *}$ & $(0.003)$ & $(0.002)^{* *}$ & $(0.003)$ & $(0.002)^{* *}$ & $(0.002)$ \\
\hline \multirow[t]{2}{*}{2008} & -0.024 & -0.025 & -0.021 & -0.012 & -0.026 & -0.024 \\
\hline & $(0.002)^{* *}$ & $(0.003)^{* *}$ & $(0.002)^{* *}$ & $(0.003)^{* *}$ & $(0.002)^{* *}$ & $(0.002)^{* *}$ \\
\hline
\end{tabular}




\section{Table 8. Continued}

(6)

(7)

(8)

\begin{tabular}{|c|c|c|c|c|c|c|}
\hline$\Delta \ln E$ & CB & $\mathrm{CU}$ & CB & $\mathrm{CU}$ & CB & $\mathrm{CU}$ \\
\hline \multirow[t]{2}{*}{2009} & -0.036 & -0.053 & -0.036 & -0.031 & -0.032 & -0.035 \\
\hline & $(0.002)^{* *}$ & $(0.003)^{* *}$ & $(0.002)^{* *}$ & $(0.003)^{* *}$ & $(0.002)^{* *}$ & $(0.003)^{* *}$ \\
\hline \multirow[t]{2}{*}{2010} & -0.026 & -0.044 & -0.035 & -0.044 & -0.024 & -0.039 \\
\hline & $(0.002)^{* *}$ & $(0.003)^{* *}$ & $(0.002)^{* *}$ & $(0.003)^{* *}$ & $(0.002)^{* *}$ & $(0.002)^{* *}$ \\
\hline \multirow[t]{2}{*}{ Constant } & -0.002 & -0.002 & 0.015 & 0.015 & 0.004 & 0.004 \\
\hline & $(0.002)$ & $(0.002)$ & $(0.002)^{* *}$ & $(0.002)^{* *}$ & $(0.002)^{* *}$ & $(0.002)^{* *}$ \\
\hline Fixed-Effects & Y & Y & Y & Y & Y & $\mathrm{Y}$ \\
\hline$N$ (firm years) & 50,036 & 22,726 & 50,036 & 22,726 & 50,036 & 22,726 \\
\hline
\end{tabular}

* signifies significance at $5 \%$ level; ${ }^{* *}$ signifies significance at $1 \%$ level. Standard errors are shown in parentheses.

\section{References}

Altunbas, Y., Evans, L. \& Molyneux, P. (2001). Bank ownership and efficiency, Journal of Money, Credit and Banking, 33(4): 926-54. DOI: https://doi.org/10.2307/2673929.

Berger, A. \& Mester, L. (1997). Inside the black box: What explains differences in the efficiencies of financial institutions?, Journal of Banking and Finance, 21: 895-947. DOI: https://doi.org/10.1016/S0378-4266(97)00010-1.

Berger, A., Miller, N. Petersen, M. Rajan, R. \& Stein, J. (2005). Does function follow organizational form? Evidence from the lending practices of large and small banks, Journal of Financial Economics, 76: 237-269. DOI: https:// doi.org/10.1016/j.jfineco.2004.06.003.

Birchall, J. (2013). Resilience in a Downturn: The Power of Financial Cooperatives. ILO, Geneva.

Burdín, G. \& Dean, A. (2009). New evidence on wages and employment in worker cooperatives compared with capitalist firms, Journal of Comparative Economics, 37: 517-533. DOI: https://doi.org/10.1016/j.jce.2009.08.001.

Capelli, P.H. \& Keller, J.R. (2013). A study of the Extent and Potential Causes of Alternative Employment Arrangements, Industrial and Labor Relations Review, 66(4): 874-901. DOI: https://doi.org/10.1177/001979391306600406.

Craig, B. (1997). The long-run demand for labor in the banking industry, Federal Reserve Bank of Cleveland, Economic Review, 33(3): 23-33.

Craig, B. \& Pencavel, J. (1992). The Behavior of worker cooperatives: the Plywood companies of the Pacific Northwest, American Economic Review, 82(5): 1083-1105.

Emmons, W.R. \& Schmid, F.A. (1999). Credit Unions and the Common Bond, Federal Reserve Bank of St. Louis Review, 81(5): 41-64.

Fama, E.F. \& Jensen, M.C. (1983). Separation of Ownership and Control, Journal of Law and Economics, 26: 301-25. DOI: https://doi.org/10.1086/467037.

Feinberg, R.M. (2001). The Competitive Role of Credit Unions in Small Local Financial Services Markets, The Review of Economics and Statistics, 83(3): 560-563. DOI: https://doi.org/10.1162/00346530152480207.

Ferri, G. (2012). Credit cooperatives: Challenges and opportunities in the new global scenario. Paper presented at the Euricse International Conference "Promoting the understanding of cooperatives for a better world", 15-16 March 2012, Venice-San Servolo. DOI: https://doi.org/10.2139/ssrn.2042511. 
Ferri, G. Kalmi, P. \& Kerola, E. (2014). Does bank ownership affect lending behavior? Evidence from the Euro area, Journal of Banking and Finance, 48: 194-209. DOI: https://doi.org/10.1016/j.jbankfin.2014.05.007.

Ferri, G, \& Kalmi, P. (2014). Only Up: Regulatory Burden and Its Effects on Credit Unions. Filene Research Report, Wisconsin.

Fraser, D. \& Zardkoohi, A. (1996). Ownership structure, deregulation, and risk in the savings and loan industry, Journal of Business Research, 37: 63-69. DOI: https://doi.org/10.1016/0148-2963(96)00027-6.

Fulton, M. \& Lang K. (2006). The Saskatchewan Wheat Pool Share Conversion. Working paper, Department of Agricultural Economics, University of Saskatchewan.

Goddard, J., McKillop, D. \& Wilson, J.O.S. (2002). The growth of US credit unions, Journal of Banking and Finance, 22: 2327-2356. DOI: https://doi.org/10.1016/S0378-4266(01)00203-5.

Heshmati, A. (2001). Labour demand and efficiency in Swedish savings banks, Applied Financial Economics, 11: 423-433. DOI: https://doi.org/10.1080/096031001300313983.

Jones, D.C. \& Kalmi, P. (2015). Membership and Performance in Finnish Financial Co-operatives: A New View of Cooperatives?, Review of Social Economy, 73(3): 283-309. DOI: https://doi.org/10.1080/00346764.2015.106 7753.

Jones, D.C., Kalmi, P. \& Kauhanen, A. (2012). The Effects of General and Firm-specific Training on Wages and Performance: Evidence from Banking, Oxford Economic Papers, 64(1): 151-75. DOI: https://doi.org/10.1093/ oep/gpr013.

Jones, D.C., Kalmi, P. \& Jussila, I. (2016). The Determinants of Membership in Cooperative Banks: Common Bond versus Private Gain, Annals of Public and Cooperative Economy, 87(3): 411-432. DOI: https://doi.org/10.1111/ apce. 12135 .

Jones, D.C. \& Pliskin, J. (1989). British Evidence on the Employment Effects of Profit Sharing, Industrial Relations, 28(2): 276-298. DOI: https://doi.org/10.1111/j.1468-232X.1989.tb00869.x.

Klinedinst, M.A. (2012). Going Forward Financially: Credit Unions as an Alternative to Commercial Banks, Advances in the Economic Analysis of Participatory \& Labor-Managed Firms, 13: 3-21. DOI: https://doi.org/10.1108/S0885$3339(2012) 0000013005$.

Klinedinst, M.A. (2016). Bank Decapitalization and Credit Union Capitalization: The Impact of Excessive Compensation. Sage Open, January-March: 1-15. DOI: https://doi.org/10.1177/2158244016630031.

Kruse, D.L. (1991). Profit Sharing and Employment Variability: Microeconomic Evidence on the Weitzman Theory, Industrial and Labor Relations Review, 44(3): 437-53. DOI: https://doi.org/10.1177/001979399104400303.

Kumbhakar, S., Heshmati, A. \& Hjalmarsson, L. (2002). How Fast Do Banks Adjust? A Dynamic Model of LaborUse with an Application to Swedish Banks, Journal of Productivity Analysis, 18: 72-102. DOI: https://doi. org/10.1023/A:1015756527109.

Kurtulus, F.A \& Kruse, D.L. (2016). How did employee ownership firms weather the last two recessions? In: F.A. Kurtulus \& D.L. Kruse (Eds.), Employee Ownership, Employment Stability and Firm Survival: 1999-2011, Upjohn Institute, Kalamazoo.

Mäkinen, M. \& Jones, D.C. (2015). Comparative efficiency between cooperative, savings and commercial banks in Europe using the frontier approach, Annals of Public and Cooperative Economy, 86(3): 401-20. DOI: https://doi. org/10.1111/apce.12060.

Megginson, W.L. \& Netter, J.L. (2001). From State to Market: A Survey of Empirical Studies on Privatization, Journal of Economic Literature, 39(2): 321-389. DOI: https://doi.org/10.1257/jel.39.2.321.

Patin, R.P. Jr. \& McNiel D.W. (1996). Credit Union Safety and Parent Organization Employment Stability, Journal of Financial and Strategic Decisions, 9(1): 89-99.

Pencavel, J., Pistaferri, L. \& Schivardi, F. (2006). Wages, employment, and capital in capitalist and worker-owned firms, Industrial and Labor Relations Review, 60: 23-44. DOI: https://doi.org/10.1177/001979390606000102. 
Rasmusen, E. (1988). Mutual banks and stock banks, Journal of Law and Economics, 31: 395-422. DOI: https://doi. org/10.1086/467162.

Taylor, R. (1979). Demand for labour by credit unions, Applied Economics, 11: 333-340. DOI: https://doi. org/10.1080/758531545.

Walsworth, S. (2010). Unions and Employment Growth: the Canadian Experience, Industrial Relations, 49: 142-56. DOI: https://doi.org/10.1111/j.1468-232X.2009.00591.x.

Walter, J. (2006). Not your father's credit union. Federal Reserve Bank of Richmond, Economic Quarterly, 92(4): 353377.

Wilcox, J. \& Dopico, L. (2011). Credit union mergers: efficiencies and benefits. FRBSF Economic Letter 2011-28. 